\title{
The Construction Research Of University Sports Culture Under The Background Of One Belt And One Road
}

\author{
Zhanke ma ${ }^{1}$ \\ ${ }^{1}$ Physical education institute, NingXia Normal University, Guyuan, NingXia, China
}

Keywords:One belt and Oneroad, college sports, sports culture, the culture construction

\begin{abstract}
Colleges and universities sports culture is an important part of college campus culture, is a kind of culture of close contact between teachers and students in colleges and universities. In this paper, the colleges and universities sports culture, analyzed the Chinese area of strategic influence on China's university sports culture and one belt one road were summarized, all the way along the way and the area under the background of college sports culture development was analyzed.
\end{abstract}

\section{Introduction}

From China has been through the northwest, southwest, central Asia, the Middle East, Russia, and then to Europe, and then from the southeast coastal sea, southeast Asia, South Asia, the Arabian peninsula to the east African coast, whole Eurasia and half in Africa were covered in this huge project. Chinese version of the Marshall plan, the American Europe, Latin America, and to establish themselves as the core of the economic system. In China today the whole Europe and Asia, and to build their own system of the republic of China. Although the implementation of the strategy, methods of is different, but are expanding their own economic hinterland, market strategy. Output the excess capacity, strong domestic funds, and the internationalization of the renminbi is the core of the Chinese version of the Marshall plan [1]. The area covering all the way of Eurasia countries is China to expand the sphere of influence, in the future also is the best space to plan accordingly. The powerful navy and the traditional system of Marine trade, coupled with weak surrounding countries, prompting and ensures that the U. S. can develop Europe, Japan, Korea, Latin America, away from the heart of the local. Around China has half of the world's population, is probably half the world's gross domestic product in the future, China developed land transportation system and large Numbers of ocean-going fleet, is to make China itself as the core, gradually to southeast Asia, central Asia, Russia power expanding sphere of influence[1]. Different conditions, the implementation of the scheme is also different. Traditional Chinese tributary system was thoroughly smash after the opium war, such a system is a kind of diplomatic strategy conforms to China's geopolitical strategy pattern, it ensures that China's surrounding countries are small and weak and obey their own, also makes China cannot go to has a particularly strong military strength can guarantee security. But the pattern of the new China of the tributary system is broken, appeared around Japan, Russia, the United Kingdom (India), and later the United States, these enough to win the world powers, China's 100 years has been in a state of absolute not safe[1]. Today, China has become the world's second-largest economy, the old continent after the European Union, but the potential is far greater than the EU's big MAC, the collapse of the Soviet union, ties, India's own development and other reasons make it hard for these countries to another threat to the present China, and China's strong production capacity and strong capital began to flock to the surrounding, once again, we use economic power and civilian power cannot threat to the surrounding country. One Belt And One Road plan as well as a new tributary system, the entire Eurasian into Huawei in the core of economic and geopolitical system.

\section{The connotation between spirit of college sports culture and one belt one road}

One Belt And One Road includes two main line, as shown in figure 1: land and sea silk road, west and east respectively, the Chinese capital, products exported to the world, and welcome to the world capital and technology into China, the plan and the past of reform and opening up, it was China lags behind other countries when facing east means open to the developed system of Marine economy, 
capital, technology rooted in coastal areas, led to the rise of gold coast of eastern China. This plan is today China herself as a mature, open and huge economic system, the more hope that the domestic capital, advanced technology to the surrounding behind the southeast Asia, South Asia, the Middle East, central Asia, Russia and the European debt crisis, trying to create China's own global pattern. The building of the structure of China's various industries have extremely profound influence, also puts forward the new requirements of development in the field of sports culture[1].

\section{ONE ROAD, ONE BELT}

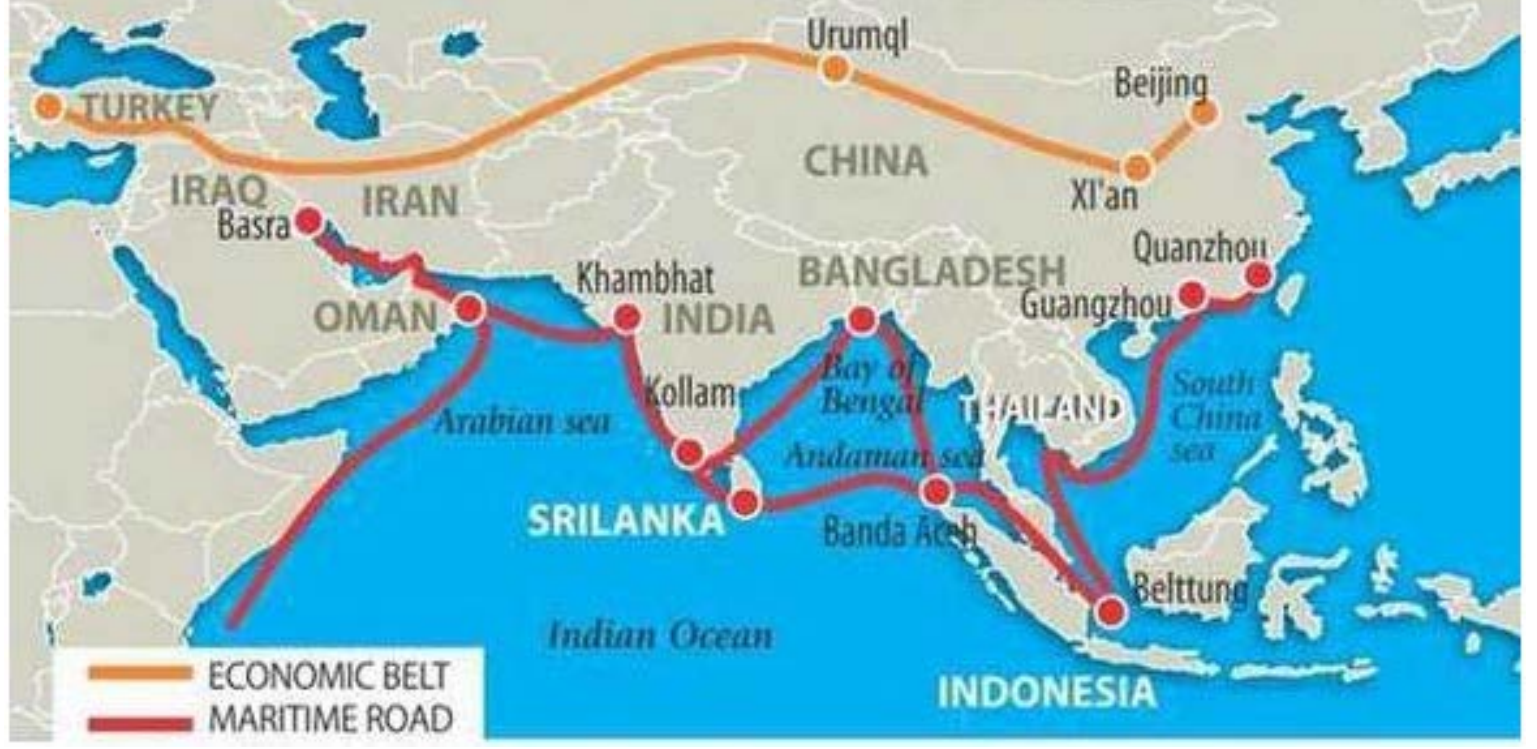

Fig. 1 One belt one road map

School sports culture is the campus culture and sports culture, infiltration, and promote and influence each other, fusion, to campus for the space, with student teachers to participate in the main body, by means of physical exercises, in the process of sports teaching, scientific research and management together create the sum total of material wealth and spiritual wealth. From the cultural point of view, people according to different cultural elements, the school sports culture can be divided into three categories, namely school sports material culture, system culture and spiritual culture[2]. And spiritual culture refers to the spirit of the school sports life style and ideology, including sports values, sports consciousness, sports attitude, sports behavior way of thinking, emotional and aesthetic temperament and interest, and so on, is the core of the whole system. Behavior culture, material culture is the external performance of spiritual culture. Therefore, to create a good school sports spirit culture is the core of the construction of campus sports culture.

Area of the modern movement, all the way through one hundred years and more and more thriving, one of the reasons is that it in its development course, gradually formed its own complete system of thought, which in the area along the movement rose to a new level, make the area along the movement of the specific activities have clear guiding ideology[2]. One Belt And One Road ideology is the area along the socialism as the core, through the area along the purpose, in spirit, all the way along the aphorisms to reflect and maintain its specific sport development. Understanding of the area along the thought Angle, is anyone guess, but I tried to explain area thought all the way from another Angle, that is "peace, friendship, fair competition, have the courage to participate in, the positive enterprising; harmonious development and comprehensive progress. "

School sports significance and current situation of the construction of spiritual culture. With the advancement of quality education and school sports the establishment of "health first" guiding ideology, the school sports culture construction have made outstanding achievements. Among them, mainly on physical education curriculum construction material culture construction is the most significant. But when it comes to the school sports spiritual culture construction, do not have clear guiding ideology, also do not have the specific construction measures, let alone the outstanding achievement[3]. Therefore, from the point of overall process, school sports culture construction achievements of confined to individual breakthrough point, has not yet formed the whole 
advancement. In addition, the influence of traditional Chinese culture and cognitive limitations, and subjective factors restricting the construction of the school sports culture. No matter from the Chinese traditional culture development process or from the point of school sports development history, "heavy text light arms" is a widespread phenomenon in the past dynasties, the value orientation of "exam-oriented education", from a certain extent adds to the people of the concept of identity, gives its breeding ground soil[3]. Therefore, in terms of the whole society, people look down on school sports, is unable to correctly measure its social status; In terms of the school, the campus sports culture atmosphere is chaotic, the utilitarian color spread; In terms of the individual students, interest in sports is not high, the lack of enthusiasm, not form a good sports attitude, sports awareness and correct values. And the training goal is to let students get the balanced development of moral, intellectual, physical, etc. Construction of school sports spiritual culture, we should also "advancing with The Times" and "people-oriented", seek and create a harmonious development of environment and atmosphere, to promote and coordinate the all-round development of students in other aspects.

One Belt And One Road idea and the inner point of school sports spirit culture construction. The goal of the school sports work in different schools, different stages have different embodiment. But the general guiding ideology is consistent, namely by taking this kind of education means, causes the student to achieve the harmonious development of body, mind, sets up the lifelong sports consciousness, and cultivate a kind of tenacious struggle, active spirit of sports[4]. One Belt And One Road thought is seeking of combination of sports and culture, education, advocated by enhanced physique, will and cultivate noble sentiment, make the person get the all-round development of body, mind and spirit. It is a kind of life philosophy, life philosophy. "Peace, friendship and progress" and "faster, higher, stronger" is the main content area along the spirit of highly concentrated, reflect is a constantly transcend self, beyond the limits of spirit. Therefore, from the point of view, "the pursuit of harmonious and unified development; pay attention to the education function; advocating self-reliance spirit" is the area along the correspondences of inner thoughts with the spirit of the school sports culture.

\section{Building the school sports spiritual culture with One Belt One Road ideas}

Set up the construction of the "people-oriented" concept. Famous American jurist Lawrence says, if there is no people's behavior, the rules is just a bunch of words, and the lack of conclusion is just forgotten the skeleton of life. So where is the true meaning of education? The true meaning of education, in a people-oriented stick. The root of education is people-oriented, comply with the man of genius, and improve one's potential, complete and full care for human development. The concept of "people-oriented" is the most appropriate expression of this purpose is put forward. The idea is not only reflected in the field of education, and had refraction to each field of the society[4]. Now, in the "peace and development" as the theme in the new era, "people-oriented" concept of the Olympic Games has become the theme of new century area along the way. The school sports work as an important part of education, should also follow the "people-oriented". Sets up the humanist education idea, in line with everything for students, in order to all students, for students of all spirit, cultivate and shape the university sports culture, build a rich campus culture atmosphere. Through all the education teaching of students take the initiative to actively participate in the desired purpose, to believe in the potential of each student, guide the student individuality to obtain the best development. And this is what area along the thought education and school sport spirit culture construction of savory point again and again and again. We want to put the idea of humanistic Olympics through to the real practice in the construction of campus culture, let every student can participate in sports, enjoy the pleasure of sports.

With "the harmonious development, the comprehensive progress" thought all the way to cultivate students scientific sports values. Sports values of sports this social phenomenon is both people and society need the notion of degree, it decides the choice of sports behavior and people to the understanding of the role and significance of sports. Including sports interest, sports motivation, sports habits, sports attitude, sports behavior standard, etc[5]. The purpose of school sports spirit culture construction is to improve students' health, developing students' consciousness of lifetime 
sports, set up the correct sports values. For a long time, because the biased understanding of the sports society, and the misleading of some physical education thought in modern times, make the fun of sports teachers blindly cater to students at the grass-roots level, "sheep" sports teaching model existed for quite a long time, so that the students from physical education should be free activities such mistake understanding, students participate in sports activities form a single, rigid, the content of the gender difference is bigger. Seriously affected the students' enthusiasm to participate in sports and sports attitude, correct understanding, did not form good habits of physical exercise and sports behavior, and the consciousness of lifelong sports. In addition, most of the students is forced by learning tasks, for lack of understanding of sports consciousness is weak, cannot arrange time reasonably to engage in physical exercise, make each stage of the students' physique condition gradually decline.

"Have the courage to participate in, proactive" in the spirit all the way to cultivate students correct sports consciousness and tenacious spirit. Sports consciousness refers to the individual student's interest in sports, sports attitude, sports habits and behavior of comprehensive reflection. For a long time, because of our physical education teaching mode single, boring, blindly emphasizes the overall uniformity, consistency, largely eliminated the student individuality, which affect the students' enthusiasm to participate in sports and correct understanding of sports. Coupled with the past of "swifter, higher, stronger" the maxim deep meaning of the one-sided understanding; Social public opinion and people's expectations of the athletes is too high, too much to players brought huge, invisible pressure[5]. Such as Japan's famous marathon runner, before the game is recognized as an Olympic medal in order not to disappoint, he suffered extreme intensity of training, but the performance is not growth, finally he committed suicide;similar suicides among athletes and British sprinter and the former Soviet Union jumper etc. Too many instances caused the student to the physical understanding bias, make students have the view that sports just athletes, and has nothing to do with personal;Sports participation has to be at the expense of the body and mind health in exchange for the outstanding athletic achievements, and so on. Creating a psychological fear and escape.

Noble One Belt And One Road socialist student's moral sentiment and the concept of law. People's moral quality as a whole, the sports moral quality is an organic part of the whole. Noble sports moral quality of the individual is formed the basis of good moral character of social sport, and good social sports style and create conditions for forming individual noble sports moral quality. The formation of sports moral quality is not innate, also is not natural, it is the formation of an objective and subjective, the external cause and internal cause dialectical unification process[6]. At present, in our country all levels of schools, a widespread abuses, namely too focused on the performance comparison between each school, while ignoring the establishment of the friendship between each other, often get flushed, for the sake of a few points to lip phase. Even under the guise of excellent athletes posing as his school team hand or regardless of personal safety, life it adopted some unethical and illegal despicable means to participate in the competition, in order to scramble for places. These behavior a serious breach of the area along the idea in the first place. One Belt And One Road spirit advocates a kind of fairness, justness and fairness, against violence, drug, and advocated "fee e game" fair competition. In school physical education in the construction of spiritual culture, therefore, we always want to the thought of "peace, friendship and fair play" to education students establish the noble moral sentiment and the legal system idea, put an end to some erosion of alienation thought.

Implementation in thought all the way with the spirit of the school sports culture construction of external fusion. School sports culture construction including material culture, system culture and spiritual culture construction[6]. Although the construction of spiritual culture is the core of its construction, but it must be a certain physical form. PE, recess activities, interest groups and sports games, sports and so on a series of organization is the specific way of its implementation. Among them, the physical education and extracurricular activity is the main way for students to participate in sports, therefore, we should put in the specific content of thought all the way through to the usual physical education and extra-curricular activities[4]. In addition can also use the slogan, approved, propaganda media such as broadcasting, campus network in games, sports and other 
activities such as sports seminar, speech contest, exhibition activities such as sports knowledge competition, image data. These colorful organization forms can all the way to school sports spiritual culture and area has provided a broad platform for the construction and route of transmission.

One Belt And One Road thoughts and the sustainable development of school sports spirit culture construction. School physical education is the foundation of the national sports, its education group is the most dynamic of teenage children, in this age is one of life and accept education, form the correct outlook on life and values the important stage. Lost for some years, such as that appeared on the social ideal and responsibility, indifference, value loss, and the problem such as money worship, hedonism, in a certain sense it is lost as a result, the humanistic spirit and humanistic spirit cultivation mainly depends on the ideological education[6]. School sports spirit culture is the important of school sports ideology, good school sports spirit culture more conducive to students to form scientific sports values, set up the correct sports consciousness, and better accept, understand and spread area thought all the way. Thought all the way as the area of "peace, friendship, fair competition; to participate in, positive enterprising; harmonious development and comprehensive progress" the idea of light have been refraction to the hearts of every one of us. But with the development of modern society, One Belt And One Road movement in the dissimilation phenomenon, such as excessive competition, winning consciousness, extreme utilitarianism, scientism, etc., from another side, also affect the school sport spirit culture construction. Therefore, we must scientifically and objectively look at all the thoughts, always establish "people-oriented" education philosophy, to correctly handle school sports spiritual culture construction and the relationship between the thought all the way, realize the sustainable development of the road.

\section{Summary}

Colleges and universities sports culture by its unique cultural atmosphere, has a subtle influence on the masses of teachers and students, so the university sports culture construction is to develop the Chinese nation traditional sport culture, and to introduce international advanced sports culture. One Belt And One Road development, on the one hand to teach students the rules of sports values, culture and sport skills, on the other hand to continually accept the world sports culture and the spirit of The Times to enrich them to the sports education.

\section{References}

[1] X. L. Song, One Belt And One Road strategy, China news journal, 2017, vol. 4, pp. 2-5.

[2] Ch. L. He, College physical education should cultivate students' science and competition consciousness, Chinese school sports journal, 2013, vol. 6, pp. 21-26.

[3] X. J. Huang, Creating the atmosphere of campus sports culture, Strengthen the students' comprehensive quality training, sports science, 2014, vol. 2, pp. 54-57.

[4] Z. H. Xu, The rational knowledge of the construction of campus sports culture in colleges and universities, Nantong engineering journal, 2004, vol. 6, pp18-22.

[5] G. H. Liu, Theory of sports in building a harmonious society, Hubei sports science and technology, 2005, vol. 10, pp. 32-35.

[6] Y. M. Huang, Sports industry development and the research of building a harmonious society, Reform and development, 2016, vol. 2, pp. 41-44. 